\title{
On the Fishery Potential of the Sea Waters of the Canadian North
}

\author{
M. J. DUNBAR ${ }^{1}$
}

\begin{abstract}
Fishery potential in the arctic water (water originating in the Arctic Ocean) is negligible. The subarctic, mixed water region is much more productive and supports marine fisheries at present. There is a need for modern methods of processing to meet present market demands. Attention is drawn to the possibilities offered by certain species, such as the Greenland shark, Greenland halibut, capelin, redfish and pink shrimp. The importance of marine climatic change is emphasized.
\end{abstract}

RÉSUMÉ. Sur le potentiel de pêche des eaux marines du Nord canadien. Dans les eaux arctiques (originaires de l'océan Arctique), le potentiel de la pêche est négligeable. Le Subarctique, région d'eaux mixtes, est beaucoup plus productif et alimente déjà des pêcheries maritimes. Pour satisfaire aux demandes du marché actuel, il y a un besoin pressant de méthodes modernes de traitement du poisson. On attire ici l'attention sur les possibilités qu'offrent certaines espèces, comme le requin du Groënland, le flétan du Groënland, le capelan, le sébaste et la crevette. On insiste sur l'importance des changements du climat marin.

PЕЗЮМЕ. Рыбнье резервы морей Канадского Севера. Запасы рыбы в полярных водах (т.е. в водах, берущих начало в Северном Ледовитом океане) весьма незначительны. Районы смешанных вод, расположенные южнее, более продуктивны и в настоящее время являются базон морского рыболовного промысла. Для удовлетворения растущих потребностей рынка необходимо внедрять более современные методы обработки рыбной продукдии. В статье указывается на перепективность ряда видов рыб таких, как, например, полярная акула, чернокорый палтус, мойва, красная нерка и чилим, а также подчеркивается влияние изменений морского климата на рыбное хозяйство Канадского Севера.

\section{DEFINITIONS}

In this paper, the "sea waters of the Canadian North" are defined as the waters north of the Canadian continental limits (the outer northern limits of the Arctic Islands), within the sector subtended by the western and eastern limits of northern Canada at the North Pole; the waters between the Canadian Arctic Islands (Queen Elizabeth Islands), Baffin Bay, Foxe Basin, Hudson Bay, Hudson Strait, Ungava Bay, the western part of the Labrador Sea, and the northern part of the Gulf of St. Lawrence. In all these regions, although only minimally in the Gulf of St. Lawrence, water from the upper 200 metres of the Arctic Ocean plays an important part in the total water mass, and the surface freezes during the winter. Surface temperatures vary from about $-1.5^{\circ} \mathrm{C}$. to about $10^{\circ} \mathrm{C}$. in summer.

The term "fishery" is applied to the commercial exploitation of the living

${ }^{1}$ Marine Sciences Centre, McGill University, Montreal. 
populations of the sea, vertebrate and invertebrate, animal and plant, but excluding the mammals and the birds. The sea mammals and sea birds, although certainly "exploitable", are either protected by law or are otherwise unsuited to exploitation on the grounds of vulnerability; exploitation would expose them to serious hazard, including the possibility of extinction, if used above the present levels. Two northern species of birds, the Labrador duck and the great auk, have already been extinguished, and one species of mammal has been pushed very close to extinction (the bowhead whale).

\section{THE DETERMINANTS OF MARINE PRODUCTIVITY}

In the sea, as on land, the basic production is at the plant level. Plants use light energy from the sun, together with inorganic salts (phosphates, nitrates, silicates, etc.) and carbon dioxide gas, to produce sugars, proteins and fats, in the presence of catalytic pigments; no other forms of life can do this. Animals use these larger-molecule materials as food. It is therefore clear that light and inorganic nutrients are essential for organic production. Temperature, at least in aquatic environments, is not a limiting factor.

The relative unimportance of the temperature of the water is at once apparent on purely empirical grounds from a glance at Fig. 1. One of the most productive regions of the seas of the world, perhaps the most productive of all, is the Antarctic Ocean, and certainly the least productive is the Arctic Ocean, yet the Arctic and Antarctic have similar temperature regimes. In both regions the winter temperatures at all depths are normally below zero Centigrade, down to the freezing point at approximately $-1.8^{\circ} \mathrm{C}$. Zones of high pröduction are found in tropical and subtropical seas, such as west of South America and west of Africa, yet enormous areas of these warm seas elsewhere are very low in productivity. Finally, the temperate zones are highly productive, especially over the continental shelves.

The reason for this unimportance of temperature is that living organisms have

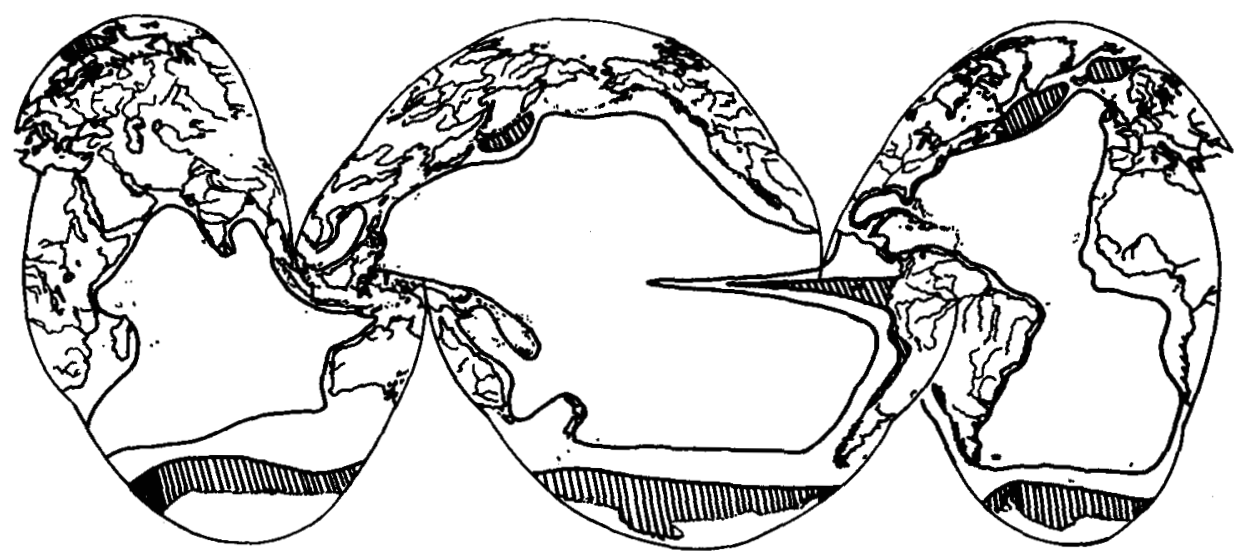

FIG. 1. World map of marine production, after Sverdrup (1955). The most productive areas are crosshatched; the next most productive areas lie shoreward of the solid line. 
evolved the ability to adjust their metabolism, and also to some extent their growth rates, to low or high temperatures according to the demands of the environment. For a discussion of this matter at greater length, see Dunbar (1968).

Having eliminated temperature as a limiting factor (an important point when considering the Canadian North), we are left with light and nutrient salts. For present purposes at least, we can also eliminate light. Although it is clear that plant cells cannot continue to grow and reproduce in the absence of light, we are concerned here not with the growth of plants on a short-term basis but with the phytoplankton growth over the unit time of one year, the seasonal cycle; and although the polar regions are undoubtedly short of light during the winter, they are very rich in light in summer, even allowing for the lower angle of incidence than is found in the tropics. Again, the wealth of production in the Antarctic is witness to the availability of ample light during the year. The presence of sea ice, particularly in the Arctic Ocean, has an important effect in reducing the penetration of light, but there is evidence that some at least of the arctic phytoplanktonic species are adapted to fairly low light intensities, analogous to the general adaptation to low temperatures.

This leaves us with nutrient salts, the fertilizers. Fig. 2 presents in very small compass the biological cycle in the sea. The important point is that by the time the breakdown of dead organic matter (detritus), from whatever source, has occurred, the resultant products in the form of inorganic salts are usually well below the level of light penetration. It follows that unless these all-important fertilizers are brought back to the surface and to the sunlit zone, they are not available for use by the plant plankton. The deep waters of all seas, even the Arctic Ocean, are rich in phosphates, nitrates and silicates; but before any given region can become productive this deep nutrient-rich water must be brought to the surface. Therefore in the last analysis the determining factor in productivity is the degree of vertical instability of the water column. The greater the vertical stability, the less the biological production.

Vertical instability in the sea, upon which high production depends, is achieved by various natural means, and inhibited by others. Wind-driven offshore currents,

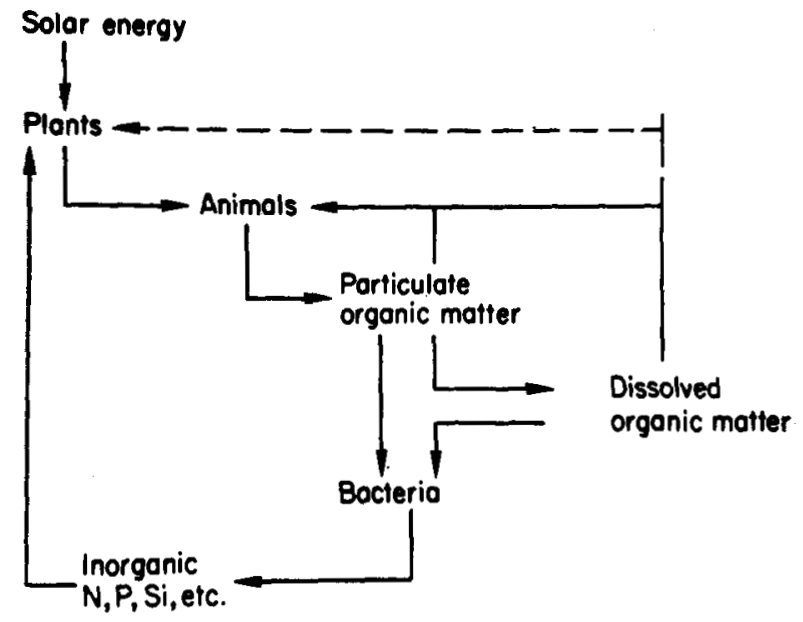

FIG. 2. Energy cycle in the biosphere. 
or offshore currents caused by the effect of the earth's rotation, induce the upwelling of replacement water from deeper layers, as along the west coasts of South America and Africa. Ice melting, cooling and sinking of surface waters, and the westerly winds round the antarctic continent, cause upwelling in the south (Antarctic Ocean). Cooling of surface water during the winter in temperate regions causes sinking and mixing. All these regions are productive for these several reasons. Vast areas of tropical and subtropical seas, warmed perpetually at the surface and subject to tropical rains, are on the other hand highly stable and relatively unproductive; and in the Arctic Ocean, which is a contained ocean and has limited means of exchange with the other oceans of the world, the freezing and melting of the surface layer cause progressive dilution which also makes for high density stratification and therefore high stability, hence chronic low productivity.

To focus the problem on the northern Canadian waters: the Arctic Ocean itself, contained by the northern shores of Siberia, Greenland, Canada and Alaska, can safely be dismissed in terms of the development of fisheries of any kind. The only possible exceptions to this are the Kara Sea (on the Siberian shelf), the coastal waters of northern Alaska, and perhaps the coastal regions off the Mackenzie Delta; and of these, two lie outside Canadian jurisdiction. It is now almost certain that any marine region which contains only arctic water, that is to say water formed in and coming from the upper 200 metres of the Arctic Ocean, will be very low in biological production and therefore not commercially exploitable for food.

South of the Arctic Ocean, however, water of non-arctic origin penetrates into the surface peripheral northern regions to various extents, and in these regions of mixed water (arctic and non-arctic), the vertical stability is reduced. In the Atlantic approaches to the Arctic, for instance, there is a broad zone in which

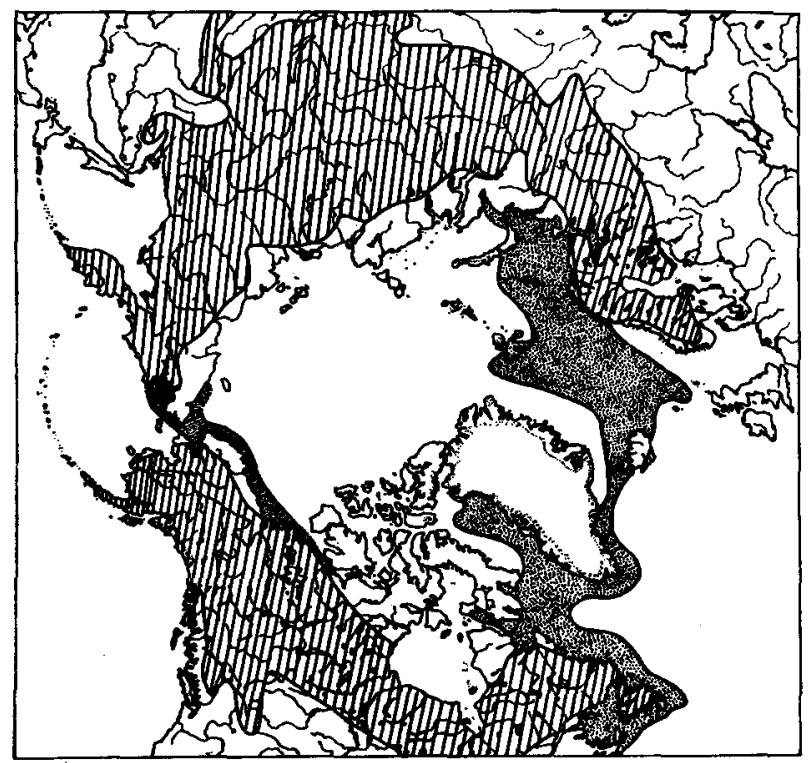

FIG. 3. The subarctic regions of the world, land and sea. The subarctic of the land (crosshatched) follows Kimble and Good (1955); the subarctic of the sea (stippled) follows Dunbar (1968). 


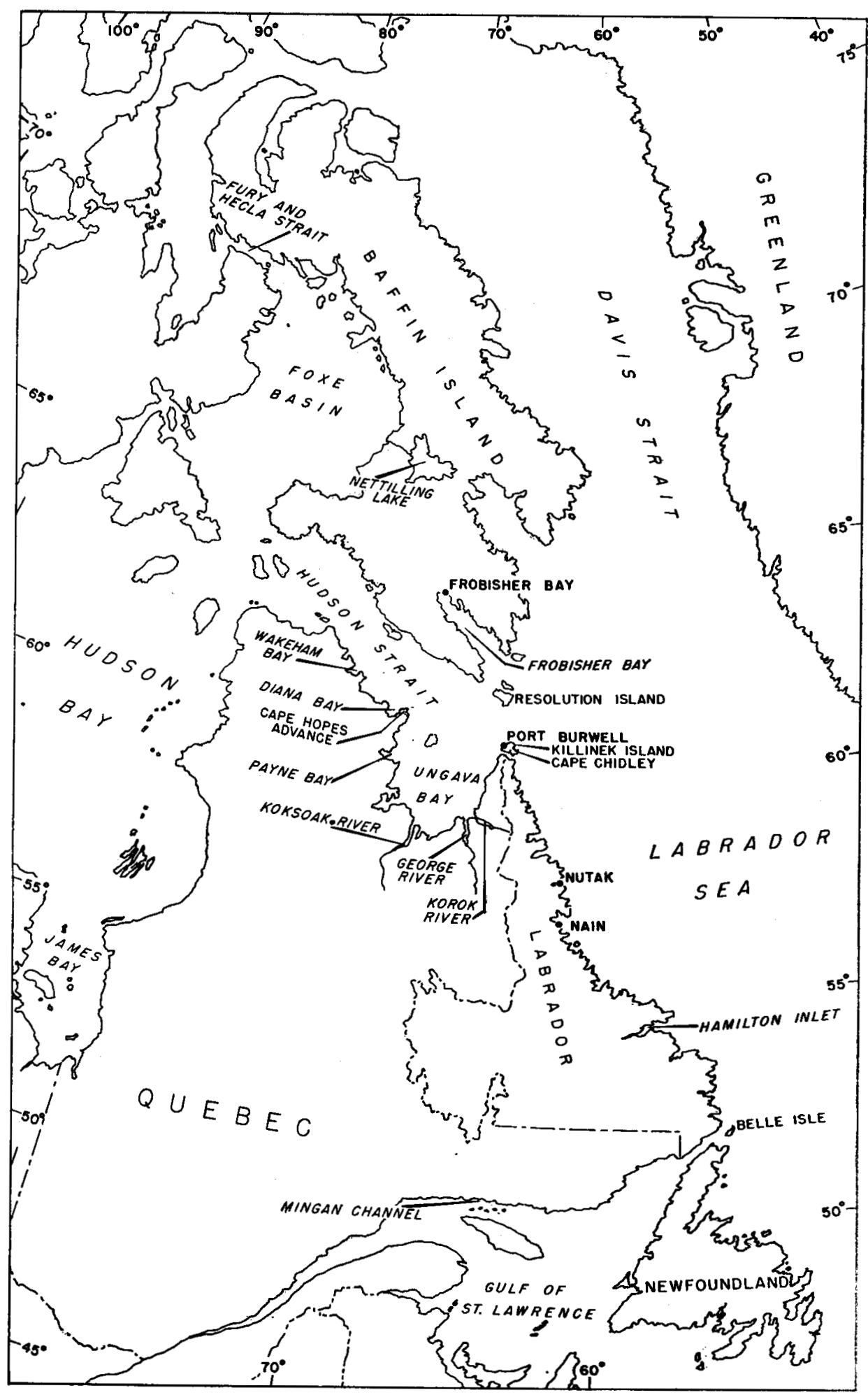

FIG. 4. Location map. 
the higher salinity of the Atlantic water reduces the density stratification. Some of the regions in this mixed zone, such as the waters off southwest Greenland, the Labrador coast, the Newfoundland banks, west and south Iceland and the southern part of the Barents Sea are among the richest in the world in terms of biological production.

This broad region of mixed water is now accepted as the Marine Subarctic, and its approximate extent is shown in Fig. 3. In northern Canada, the marine subarctic zone includes, on the Atlantic side, Ungava Bay, the Labrador Coast, the waters of Newfoundland and at least the northern part of the Gulf of St. Lawrence (see Fig. 4). On the Pacific side, Pacific water entering through Bering Strait penetrates into the Chukchi and Beaufort Seas, and its effect is apparent at the surface to some extent along the north coast of the Yukon Territory and Mackenzie region; but it should be understood from the start that the Pacific influence in these areas is very much smaller in geographical extent and in hydrographic effect than is the Atlantic water influence in the Atlantic Subarctic. Consequently the consideration here of fishery possibilities in northern Canadian seas places emphasis almost entirely upon the Atlantic, or Eastern Subarctic, area.

\section{HUDSON BAY}

Before considering this Atlantic Marine Subarctic, a word on Hudson Bay: It is very large (c. 472,000 square miles), fairly shallow and very much a Canadian inland sea. It cannot be included in the Subarctic, as defined above. The evidence of the intrusion of Atlantic water into the bay is weak, to say the least, and in summer the density stratification is intense, owing to the strong solar heating and the enormous inflow of fresh water from river systems. On the other hand, it is in a stormy area, and the turbulence caused by storms, especially in the fall, must have a significant effect in reducing the density stratification. To my knowledge the only oceanographic observations made in the winter in Hudson Bay were in 1955 (see Dunbar 1958); the measurements taken at that time showed that the stability was low, indicating the overturning of the water and therefore reasonably high production. Fairly high production in Hudson Bay is in fact the impression given by such work as has been done there, but the production is in terms of phytoplankton and zooplankton, and possibly also in terms of sea mammals (hence the whaling industry in the past in Hudson Bay). Fish are not abundant in Hudson Bay, and in fact are conspicuous for their lack of success in arctic regions (as opposed to subarctic), and also in the Antarctic. Mention of the possible value of the Hudson Bay plankton is made again below, in the section on the direct exploitation of the plankton.

In 1930 the Fisheries Research Board, then known as the Biological Board of Canada, commissioned an expedition to Hudson Bay to make an estimate of its fisheries resources. A season's work using the trawler Loubyrne produced no evidence of exploitable resource of any kind. The work of the Fisheries Research Board vessel Calanus in later years confirmed this finding, and Hunter (1968), reviewing the situation, wrote "Of a total of 64 species (of fish) belonging to 46 genera and 22 families only 17 species representing 13 genera and 9 families 
are economically important and a number of these are of very limited abundance. Only 2 species of marine fish, Greenland cod and capelin, show any potential for exploitation. These are presently fished to supplement local food supplies on the Belcher Islands and, in the case of capelin, at Churchill and south coast settlements where they occur."

The other species referred to by Hunter are freshwater and anadromous fishes, of which only 4 are of any real importance to the Eskimos of Hudson Bay. These are the arctic char, the brook trout, lake whitefish and cisco. Of these, only the arctic char can be taken at all seriously, and its possible development in the Hudson Bay area involves the same principles and rules as are described below for this species elsewhere.

This disappointing verdict for Hudson Bay stands in strong contrast to the first high hopes, which were based on no scientific studies at all (see Hunter 1968).

The quantities of Greenland cod and capelin in Hudson Bay have not been estimated. Experimental fishing for both species, say on the Belcher Islands, on a strictly practical basis, would be worth while and very interesting; but the likelihood of exploitable populations, in the view of the present writer, is low.

\section{ON ESKIMOS AND FISHES}

It is probably true to say that the Eskimos themselves have developed arctic fisheries in northern Canada to the extent possible under the conditions set by the traditional native technology. The Eskimos live, and always have lived, in an economy of scarcity, and everything available to them has been used and incorporated into their culture. The crux of the matter at hand, therefore, is to decide where northern fishery resources can in fact be developed by modern technological methods beyond the old Eskimo level, in the hope of producing a fishery comparable with, if no doubt less in volume than, the marine fishery of southwest Greenland developed by the Danes and the Greenlanders.

\section{THE FISHES}

\section{ATLANTIC COD (Gadus morhua)}

One of the really important economic fishes of the world, the Atlantic cod is found in shelf waters on both sides of the northern part of the North Atlantic and extending into the Subarctic. It ranges on the North American coast from Cape Hatteras to southeast Baffin Island, the greatest concentrations of populations being in the Atlantic Provinces including the Labrador coast, and the Gulf of St. Lawrence. To give an indication of its economic importance, the total quantity of cod landed in 1962 from the western North Atlantic, with 16 countries engaged in the fishery, was reported as 2.6 billion pounds (1.2 billion $\mathrm{kg}$.). Of this total, Canadian landings were 586 million pounds ( 266 million $\mathrm{kg}$.) valued at $\$ 18,600,000$ (Leim and Scott 1966).

In our area of interest, the Atlantic cod is fished commercially in the Gulf of St. Lawrence, and along the Labrador coast north to just north of Nutak, or roughly three-quarters of the way down the whole Labrador coast; and the cod 
forms part of the native Eskimo fishery further north than that, particularly in the Cape Chidley area, where the cod enter the vicinity of Port Burwell at the northern tip of Labrador in summer, but do not spawn there. Something of the order of 20 fish per man per hour can be caught by jigging in Forbes Sound at Port Burwell, with a wet weight equivalent of about 140 pounds $(63 \mathrm{~kg}$.). I understand that three cod traps are now (1970) operating at Burwell, and a freezing plant has been built; the amount of cod produced does not appear to have been published yet. There are plans to extend the fishery to longlining for both cod and Greenland halibut in deeper water.

In late summer (August and September) the Atlantic cod is also present in some numbers at Resolution Island in the eastern end of Hudson Strait, where it could perfectly well form the basis for a small fishery.

But the Labrador fishery needs to be radically changed and modernized if it is to hold its own in the competitive world, for salt fish is becoming less and less marketable. I quote here from Paddon and Andrews (1950):

"The markets for this product are chiefly the Mediterranean countries and

West Indies, frequently the poorer ones, and the price is low . . . The product is coarse and unappetizing, and is designed for the markets least able to pay good prices. It ignores the prosperous markets of North America, and the markets which may again open in parts of Europe. These markets, which would have no interest in dry salt cod, would perhaps welcome the delicious frozen fillets which might be produced by a fresh-fish industry ... Salting heavily in the twentieth century would appear to be nothing but an expensive way of spoiling good fish. Furthermore, almost three-fifths of the fish are thrown away, and there is no attempt to produce by-products such as fish meal. Even the oil is neglected, only part of the livers being used at all. Many fishermen discard the livers with the cleaning. The methods of preparing such liver oil as is produced, if seen by the customer, would discourage purchase." That was in 1950. The situation may be improving somewhat, but there is a long way to go, particularly in the processing of the fish on the Labrador coast itself. There have been improvements in the fishing gear used by the Newfoundland and Labrador fishermen since the quoted paragraphs were written, but what is needed is total reorganization of the industry. The fish populations themselves are large, even though they are at present under increased pressure from foreign fishermen (a witness in itself to the profitable nature of the industry as a whole and therefore potentially to the Canadian fishermen).

One has to adapt to the environment, and as humanity moves northward, adaptation takes the form of technological development and advance. The proper use of the cod fish resources of the Labrador coast, all the way to Resolution Island, requires the vision and the attack of people aware of this need for technological advance. The next stage in the "northward course of empire", so far as the Labrador fisheries are concerned, is the establishment on that coast of modern fish-processing plants which will produce frozen and packaged fish for export.

Much of what has been said about the Labrador cod fishery applies also to the north shore of the Gulf of St. Lawrence, where the resources are no less and the need for development just as great. 


\section{GREENLAND COD (Gadus ogac)}

This is a northern fish, smaller and far less populous than the Atlantic cod, seldom growing over 28 inches $(71 \mathrm{~cm}$.) in length. It is found in West Greenland waters, and west to Point Barrow, Alaska; along the Canadian mainland Arctic coast and south to the Gulf of St. Lawrence, particularly the northern part of the Gulf. It belongs to shallow inshore regions. Reaching an age of about 12 years (in West Greenland, where it is best known), it matures in 3 to 4 years and spawns in February to April. In Canadian waters it is nowhere very abundant, and its commercial importance is probably small or insignificant. There have recently been reports from the work of the Arctic Biological Station of the Fisheries Research Board that the Greenland cod is available in perhaps not insignificant numbers in the Central Arctic, in the region of Coronation Gulf $\left(68^{\circ} 00^{\prime} \mathrm{N}\right.$., $116^{\circ} 00^{\prime} \mathrm{W}$.), where up to 60 fish per man per hour were jigged. Average catches over a number of days, however, were much lower than this. As this work has progressed through the 1960's, moreover, the reports have become less enthusiastic, and tagging experiments have suggested that this species in that area is divided into local populations, all of them probably small, and that the populations will not withstand extensive fishing. The same is probably true of the Belcher Islands in Hudson Bay, as already mentioned above.

\section{ARCTIC COD (Boreogadus saida)}

A High Arctic species of small abundance except very locally, and not worth considering for exploitation. The same is true of its cousin Arctogadus glacialis.

TOMCOD (Microgadus tomcod)

Found from Hamilton Inlet south to Virginia in coastal waters, and invading brackish regions. This species is fished in the winter in the St. Lawrence River, and it is not of great exploitable value. The catch of Tomcod in the Canadian area in 1962 was estimated as $1,208,000$ pounds $(550,000 \mathrm{~kg}$.) valued at $\$ 26,000$.

\section{SAFFRON COD (Eleginus gracilis)}

A Pacific species, this fish has been taken in some numbers in the Central Arctic (Coronation Gulf region); but I think that as in the case of the Greenland cod, it is not worthy of serious consideration for development in the Arctic.

\section{ATLANTIC halibUt (Hippoglossus hippoglossus)}

This is a large species, and important. It grows frequently up to 8 feet $(2.4 \mathrm{~m}$.) in length and $400 \mathrm{lbs}$. $(180 \mathrm{~kg}$.) in weight, and larger individuals have been recorded. It is already exploited in eastern Canadian waters, including the Gulf of St. Lawrence and southern Labrador, but there is a probability that Atlantic halibut are also fairly abundant off the whole of the coast of Labrador and up to Davis Strait. Although the young develop in water of about $40^{\circ} \mathrm{F}$. $\left(4.4^{\circ} \mathrm{C}\right.$.) they can stand both colder and warmer water, and as adults they are usually caught in water that can be as cold as $35^{\circ} \mathrm{F}$. $\left(1.7^{\circ} \mathrm{C}\right.$.). They mature at about 10 years of age and spawn in the early spring, from March to May. A female halibut can produce over two million eggs. They are fished with long-line and otter trawls. 


\section{GREENLAND HALIBUT (Reinhardtius hippoglossoides)}

This is a very interesting fish, known also as "turbot" and "Newfoundland turbot", growing up to about 40 inches $(1.015 \mathrm{~m}$.) and 25 pounds $(11 \mathrm{~kg}$.) weight. It is a deep water fish of the Subarctic, ranging (in the western Atlantic region) from Georges Bank in the Gulf of Maine to Davis Strait on the Canadian side, perhaps further north, and as far north as Thule in west Greenland. It is fished commercially in Newfoundland waters, but is not common in the Gulf of St. Lawrence, so far as is known. It is excellent eating, and can be smoked most successfully.

I think this species has real possibilities for fishery development along the whole of the Labrador coast and probably up to Davis Strait off southeast Baffin Island. Young specimens have been taken in the Burwell region of Ungava Bay, by the present writer, and in fact seem to be fairly abundant there (Dunbar and Hildebrand 1952), and the adults have since been fished off Cape Chidley and in Davis Strait; up to $1,000 \mathrm{lbs}$. (454 kg.) per hour at 600 metres (Templeman 1966). In Greenland, where this fish is greatly prized, it is taken at depths of about 400 to 800 metres. An excellent, highly marketable fish. There is not much known about the biology of this species.

\section{ATLANTIC HERRING (Clupea harengus)}

Highly important in temperate and southern Subarctic waters in eastern Canada, but of doubtful value along the Labrador coast. Its appearance in Labrador waters is capricious and unreliable.

PACIFIC HERRING (Clupea harengus pallasii)

"Sizeable stocks" of this species have been reported by the F.R.B. Arctic Biological Station in the Central Arctic regions (Liverpool Bay, $70^{\circ} 00^{\prime} \mathrm{N}$., $130^{\circ} 00^{\prime} \mathrm{W}$., to Darnley Bay $69^{\circ} 45^{\prime} \mathrm{N}$., $123^{\circ} 45^{\prime} \mathrm{W}$.). As an object for development, however, this species in Arctic Canada is even more speculative than the Atlantic herring off northern Labrador. Leave it alone.

\section{CAPELIN (Mallotus villosus)}

One of the most abundant of all species of fish within its range, which is from the Labrador coast south to the Gulf of St. Lawrence and Newfoundland, and with apparently isolated populations in Ungava Bay and Hudson Bay. Also West and East Greenland, Iceland, Spitsbergen, White Sea and northern Norway. The capelin is an important food of the Atlantic cod, salmon, dogfish, seals, whales and certain birds, and it is present in truly astronomical numbers. It is small and smelt-like, up to 8 or 9 inches $(20$ or $22 \mathrm{~cm}$.) in length, and simple to catch in seines or hand-nets. It spawns along the shores from June to August, on sand and gravel beaches, mainly at night.

It is usually rare in northern Labrador and Ungava Bay, but has appeared in Ungava Bay on occasion in large numbers, as in 1884 (Turner 1885) and in 1959 (Le Jeune 1959), probably indicative of sudden upswings in the marine climate and invasion of Atlantic water from the east. It is common in James Bay and southern Hudson Bay, especially in the Belcher Islands; here it appears to be 
well established, and probably represents one of the warm-water relicts in that area, left over from a warmer climatic period and able to survive and breed because of the significant warming of the surface layers in summer.

The capelin is undoubtedly a food resource, also a fertilizer resource, which can be developed in Hudson Bay and on the Labrador coast. It could be used for fish-meal as well as for direct consumption, both for humans and for other animals. In Newfoundland, including Labrador, capelin are already used to a considerable extent, but the potential has not been realized. Of the Labrador region, where they are most abundant in the southern part, Paddon and Andrews (1950) write: “Among salt-water fish, capelin are probably the most numerous. These are used for bait and dog feed and eaten dried, usually raw or toasted. Visitors who try them usually find them delicious." And from Templeman (1966): "Eventually as fishing pressure reduces the stocks of cod, haddock, and other commercial fishes, capelin may be the most abundant fish in the area."

What goes for Newfoundland itself goes also for much of the Labrador coast; and the capelin resources of Hudson and James bays, although not yet estimated, are probably very large.

\section{REDFISH (Sebastes marinus)}

One of the uglier fishes of the sea, but very good to eat, the redfish is sold commercially as "ocean perch" or "rosefish"; also called "Norway haddock". It has a wide distribution in the northern North Atlantic, from the Barents Sea to Iceland, Greenland, Nova Scotia, Newfoundland, the Gulf of St. Lawrence, and northward up the Labrador coast to the mouth of Hudson Strait. It is a coolwater form, in the temperature range of $3^{\circ} \mathrm{C}$. to $8^{\circ} \mathrm{C}$. In size, it is most commonly taken in the 10 - to 16 -inch (25 to $40 \mathrm{~cm}$.) range, but much larger specimens are known. They prefer fairly deep water, from 60 to 350 fathoms.

The Redfish is viviparous, and the young are released in spring and summer, from May to August, in Canadian waters. Females produce about 30 or 40 thousand young per year. They are pelagic, rather than benthonic, feeders; in fact, they are really pelagic fish, although in the shallower parts of their range they go down to the bottom in the daytime. They grow slowly, depending on the temperature. At 9 inches $(22 \mathrm{~cm}$.) in length, on the average, they are about 10 years old. According to Leim and Scott (1966) the catch of redfish from the Canadian Atlantic area for 1962 was $60,079,000$ pounds $(27,240,000 \mathrm{~kg}$.), with a value of $\$ 1,571,000$.

There is a considerable literature on this species, and it appears that the redfish fishery, at least on our coasts, has reached its limits (see, for example, Tempelman 1966), except perhaps in deep water off the Labrador coast.

\section{MACKEREL (Scomber scombrus)}

An Atlantic (boreal) rather than a subarctic fish. It is included here only because it is possible that it could be used more than it is at present in the northernmost part of its Canadian range, in the northern Gulf of St. Lawrence and the Belle Isle region, where it appears in the late summer. The mackerel is pelagic and migrant, spawning in May, June and early July in Canadian waters. 


\section{ATLANTIC SALMON (Salmo salar)}

Not recommended for exploitation above the present levels, but an interesting species nevertheless. It is at present taken commercially along the north shore of the Gulf and on the Labrador coast, as well as further south. Recently, an extremely rich area of sea-run salmon has been discovered in the Labrador Sea and off southwest Greenland, and the damage done to the whole North Atlantic stock of salmon by commercial pelagic fishing has already been shown to be serious.

In Ungava Bay, the most northerly region of salmon distribution in Canada, commercial fishing for salmon was undertaken by the Hudson's Bay Company from 1881 onwards, but the output was disappointing and declined continuously, so that the fishery was finally given up in the early 1930 's. For more details, see Dunbar and Hildebrand (1952).

\section{ARCTIC CHAR (Salvelinus alpinus)}

One of the best table fishes that the world produces; known by a variety of confusing names, such as "sea trout", "Hudson Bay salmon", and "Hearne salmon"; also increasingly by its Eskimo name which the Department of Northern Affairs has attempted to establish as "elkalu", which is nothing very like the actual Eskimo word. In Eskimo the word is pronounced with the guttural " $k$ " or " $q$ " sound, and the closest English transliteration is "ek'aluk" or perhaps "ekraluk".

Like the Atlantic salmon, the arctic char is an anadromous, sea-run fish, breeding in fresh water. It has a circumpolar Arctic and Subarctic distribution, and is fished commercially in West and southeast Greenland, and in Frobisher Bay and the northern part of the Labrador coast. It is known to reach a length of about 38 inches (over $1 \mathrm{~m}$.) and a weight of at least 26 pounds $(12 \mathrm{~kg}$.); but such sizes are rare. In ordinary catches, fish over 10 pounds $(4.5 \mathrm{~kg}$. $)$ in weight are not common. There are many "landlocked" populations in individual lakes and lake systems, which have given rise to pleasant taxonomic confusion and variety in size and colour. Landlocked populations are fished by the Eskimos, as are the sea-run stocks, but only the latter can be considered for commercial or semi-commercial exploitation. The Danes in Greenland have known for a long time that in order to conserve this excellent fish under conditions of commercial exploitation, it is necessary to study each area independently and to set rigid limits to the annual take. Ideally, the take in any given region should be spread over as many streams and stream-mouths as possible, which means that the fishery must be equipped with powerboats to give the necessary mobility.

The reasons for these precautions are simple: the char spend only from one to two months per year in the sea, when most of their feeding is done; the water is cold and the production levels usually fairly low. Consequently, the char grow and mature slowly. On the west coast of Hudson Bay the sea-run fish reach lengths of some 20 inches $(50 \mathrm{~cm}$.) in 10 years, landlocked populations much less, about 12 inches $(30 \mathrm{~cm}$.). Sea-run fish in the Sylvia Grinnell River in Frobisher Bay, Baffin Island, are only 13 inches $(33 \mathrm{~cm}$.) long in 10 years, 25 inches $(63 \mathrm{~cm}$.) at 20 years (Grainger 1953). Some of the char in Frobisher Bay may be 24 years 
old or more. Furthermore, the females probably do not spawn every year once they have reached maturity, but only in alternate years, and they may take from 6 to 12 years to mature. Once mature, they produce from 2,700 to 7,000 eggs per spawning, which is not a large number, and there is a large early mortality from predation, particularly from cannibalism. It is easy to fish out and destroy a local stream population, and recovery will be very slow.

The arctic char has been studied actively by the Arctic Biological Station of the Fisheries Research Board since 1948, and controlled commercial operations have been begun at Frobisher Bay and at Port Burwell and Nain, and generally in northern Labrador. The Labrador fishery maintained by the Eskimos is an old one, and has been mainly for local consumption. Since 1942, the export fishery, starting in a very small way, has grown. Hunter (1965) gives figures for the catch from the Labrador Coast, marketed as salted char, from 1942 (32,340 lbs. [15,000 kg.]) to $1964(199,980 \mathrm{lbs}$. [90,000 kg.]). The standard fishing gear was the gill net.

Experimental char fishing has been carried out on Nettilling Lake, in Baffin Island, but the results so far are inconclusive; the probability is that the lake, big though it is, will not support commercial development of the char. At Frobisher Bay (Sylvia Grinnell River) one of the first of the Northwest Territories regions exploited for char, there is now an established 10,000 pounds $(4,535 \mathrm{~kg}$.) quota for the season; this quota is usually taken in the first week of fishing. There is a steady decline in catch per unit effort.

All this means that the arctic char has to be approached with care. The take per stream must be carefully estimated, and there must be a constant watch on the progress of the fishery. This means that the economics of such a fishery are tricky; much depends on the price the product can demand on the gourmet market, and this in turn depends on the processing method, among other things. Freezing, or skilful smoking, are the most promising methods; well-smoked arctic char is a delight. In fact, by any means of preservation, the arctic char, properly handled, is a far better table fish than the Atlantic salmon.

\section{AMERICAN EEL (Anguilla rostrata)}

The eel is probably underfished, because of the ignorance of the eating public. It is extremely good and extremely abundant, and there is no doubt that along the north shore of the Gulf of St. Lawrence and probably also in southern Labrador there are potential eel fisheries of some importance. The annual catch of eels in the Canadian Atlantic area is of the order of $750,000 \mathrm{lbs}$. $(350,000 \mathrm{~kg}$.), valued at about $\$ 160,000$, but with proper market development it could be very much higher.

The American eel, which according to most zoologists is the same species as the European eel, is found from the Caribbean to southern Labrador. It breeds at sea, in the Sargasso Sea region, and enters rivers along all coasts within its range of distribution. The females, the larger sex, reach lengths of about 42 inches (1.06 m.). In our area, they migrate upstream as elvers in May to July, and as they approach the size of maturity, they leave the rivers for the Sargasso area. They do not return again to fresh water; that is to say they die after spawning 
at sea. The females produce between 5 and 20 million eggs; a prolific fish awaiting appreciation and exploitation.

\section{LUMPFISH (Cyclopterus lumpus)}

A stout and ungainly fish, the lumpfish is not used commercially in North America at all, but is much appreciated in Scandinavia and in Germany. It grows up to 20 pounds $(9 \mathrm{~kg}$.) in weight and the ovaries make good caviar. It is found from Hudson Bay to the New Jersey coast, usually on rocky or stony bottoms, but spending part of its time pelagically. Its life cycle is not very well known, but it seems to spawn in spring on Canadian coasts. The precise abundance of this fish in our northern waters would have to be explored; northwest European countries use several million pounds a year.

\section{WOLFFISHES (genus Anarhichas)}

The wolffishes, or marine catfish, are large (5 to 6 feet -1.5 to $1.8 \mathrm{~m}$. - in length) and excellent to eat, and the skin, especially of the spotted wolffish (A. minor), is tanned for commercial sale. The spotted species, however, appears to be rare on our side of the Labrador Sea, though common in West Greenland. The northern wolffish ( $A$. denticulatus) is known from the northwest, in the region of Prince Patrick Island, $77^{\circ} 00^{\prime} \mathrm{N} ., 120^{\circ} \mathrm{W}$. (Leim and Scott 1966), but has not been recorded from the remainder of the Canadian north; this is surprising, since it appears to be subarctic in general distribution. The Atlantic wolffish ( $A$. lupus) is known from southern Labrador to Cape Cod, and throughout the Gulf of St. Lawrence; it is already used commercially to some extent, being handled to the extent of about three million pounds a year, valued at about $\$ 100,000$.

It is probable that the first two species are in fact present in northeast Canada, in subarctic waters, and that it has not yet been looked for with the appropriate gear or in the right places. All three species are worthy of serious consideration in the present context.

\section{GREENLAND SHARK (Somniosus microcephalus)}

The Greenland shark is another of the few northern marine fishes that are underexploited at present; in fact, it is not used at all in the Canadian North, although common there. The textbooks say that the Greenland shark has been taken up to 24 feet $(7.31 \mathrm{~m}$.) in length, but a 15 -foot $(4.6 \mathrm{~m}$.) fish is a good catch. It is a sluggish creature, by all accounts, but nevertheless able to prey upon quite large fish, and seals, and probably even whales. In view of the really interesting possibilities of this fish, I quote at length from Dunbar and Hildebrand (1952):

"Common in Davis Strait and Baffin Bay, and along the whole of west Greenland coast. In the Canadian arctic, information on its abundance is lacking, but there are indications that it is very common in certain areas . . .

"The Greenland shark is seen sporadically in various parts of the Ungava Bay coastal waters, but it is by nature a deep-water animal. These shark are occasionally killed off the mouth of Payne Bay, and they are known to be stranded sometimes at the mouths of Koksoak, Korok, and George rivers. 
At Burwell, they are reported by the natives as being very common during the time of autumn migration of the harp seals (Phoca Groenlandica) through MacLellan Strait, when they are caught in seal nets and do considerable damage to the seal hunt. The same thing, in smaller numbers, is also reported from Wakeham Bay, on Hudson Strait, and shark have always been known to be fairly common at Diana Bay and Cape Hopes Advance.

"Although the Greenland shark is clearly active enough to catch and devour seals (Bigelow and Welsh 1925), it cannot be described as a very fearsome animal, at least at the surface. It has been known by whalers to gouge out large pieces of the flesh of dead whales, as described by Scoresby (1820), but there seems little evidence for the statement by Jordan and Evermann (1896) that this fish is an enemy to whales, 'biting out large masses of flesh from their bodies'. Jensen (1925) comments on the surprising fact, a common experience in Greenland, that these sharks 'can be hauled up from such a depth (abt. $250-400 \mathrm{~m}$.) with a line no thicker than a piece of stout string, and killed from the Kyak with no other weapon but a knife'.

"Samples of shark livers were preserved in brine, and later analysed by Dr. F. A. Vandenheuvel of the Experimental Station at Halifax, with the following results:

$\begin{array}{ll}\text { Oil Content } & 60 \text { per cent approx. } \\ \text { Refractive index }\left(20^{\circ} \mathrm{C} .\right) & 1.47154 \\ \text { Iodine number } & 100 \\ \text { Vitamin A content } & 1805 \text { I.U. per gram } \\ \text { Unsaponifiable material } & 8.6 \text { per cent." }\end{array}$

The flesh of the Greenland shark, like that of most sharks, is not pleasant to eat when freshly caught; sharks secrete urea into the blood as a means of equalizing internal and external osmotic pressures, and this causes the meat to be toxic until the ammoniac products of the breakdown of urea have been dried out or leached out, after which the meat becomes perfectly satisfactory. It is used in Greenland for dog-food and, in emergency, for human food also; and it should be remembered that the meat of many members of the shark group is quite normally sold on civilized markets under such deluding names as "rock salmon", even as "scallops", and eaten happily by millions of self-styled gourmets every year, for high prices.

The meat, the liver, and finally the skin of the Greenland shark are all marketable, if properly handled. The leather is extremely tough, as is normal among sharks, and it is used for heavy upholstery, as in aircraft, for boots and shoes, and many other special purposes.

The vitamin A content of the liver, according to Danish investigations, increases northward, which is interesting but at present unexplained.

The Greenlanders are conversant with the Greenland shark, and the Danish Fisheries Research in Greenland has been studying the fish for some time, mainly from the economic point of view. I quote here passages from Hansen and Hermann (1953) in translation from the Danish: 
"The liver of the Greenland shark ... . in well-nourished specimens can occupy most of the body cavity. In such large, fat specimens the liver can weigh up to $300 \mathrm{~kg}$. In the West Greenland sharks, however, it is usually much smaller; most of the sharks taken have livers weighing between 15 and $25 \mathrm{~kg}$."

The northward movement of the shark in response to the climate warming experienced from 1920 to the 1950's (Hansen and Hermann 1953), and perhaps later, would be expected to increase rather than decrease the concentration of sharks in Canadian Eastern Arctic waters, and makes the investigation of the exploitation of this fish in our northern regions still more intriguing.

In Greenland, the annual production of shark liver was approximately 700 tons in the period 1931-39; in 1952, it was 358 tons.

A fish to remember.

\section{FISHMEAL.}

Whole fish can be processed to produce an odorless but palatable human food. It can of course also be used for animal food and for fertilizer, so that there is always a good market for it. Fish caught in trawls or on longlines, other than the particular species desired in a given fishery, can be treated in this way provided that plants are built for the purpose. In the northern parts of Canada, this applies particularly to sculpins (family Cottidae), lumpsuckers, blennies and others, found throughout the north in varying numbers. The density of the populations of these species, however, is not yet known.

\section{THE INVERTEBRATES}

No invertebrate marine species has yet been used commercially in northern Canada, and in fact the outlook is not encouraging. It is not, however, hopeless, and the braver souls among us might even think it stimulating. For one thing, we have been talking about the possibilities of exploitation of certain vertebrate species, and the possibilities have appeared to be quite real, at least in the subarctic regions as defined above. It will have occurred to the dullest intelligence that these vertebrate species must eat, and that therefore there must exist a mass of food organisms, ultimately invertebrate (and indeed plant) organisms, to support these fishes (and marine mammals). Furthermore, the mass of these food organisms must, according to well-established ecological theory, be several times greater than the mass of the organisms which feed on them. It follows that if mankind, equipped with the means of catching and processing, and with all social and trophic taboos removed, were to use this invertebrate capital directly, he would do very well. The problem, therefore, is technological and social, rather than strictly biological.

Nevertheless, our knowledge of the practical availability of the invertebrate fauna of our northern waters is still rudimentary; much field work remains to be done. 


\section{THE PINK SHRIMP, OR DEEPWATER SHRIMP (Pandalus borealis)}

The pink shrimp is by far the most important animal in this category. The life history of this shrimp is of special interest. Like several decapod crustaceans, it is a protandric hermaphrodite; each individual, after a planktonic larval life, goes through a stage as a functional male, followed by metamorphosis into a functional female stage, in which stage it remains for the rest of its life. The following account of the Greenland pink shrimp is taken (in translation) from Hansen (1949):

"... It is evident that the Greenland shrimp, in its life history, corresponds to the deep water shrimp found in Spitsbergen, and upon which the Norwegians have undertaken research work. The eggs which the female carries on her swimmerets are laid in July and hatch in the summer, and the young larvae are found in the upper layers of the water. It takes two years for the larvae to become mature males. They remain as males for two years, after which time they change sex and become females. The females are thus older and therefore larger than the males. We do not know exactly how long they remain as females, but it is at least two years, so that the shrimp live at least six years altogether. Trawling in Disko Bay has shown that the females lie farther out from the coast than the males. Trawling near the coast produces predominantly males and immature young, while trawling some sea-miles from the land yields females in much larger numbers."

Pandalus borealis has recently been discovered in large numbers in the waters of Newfoundland, the Gulf of St. Lawrence and on the Labrador coast. The present known distribution in North American waters is shown in Fig. 5. The total depth range in our region is from about 20 metres to 700 metres; but 80 percent of the population ranges from 180 to 450 metres; total temperature range is between $-1.5^{\circ} \mathrm{C}$. to $7.5^{\circ} \mathrm{C}$, with 80 percent taken between $4{ }^{\circ} \mathrm{C}$. and $6.5^{\circ} \mathrm{C}$. It is known also in the Pacific, but not farther north than Bering Strait.

Fishing commercially for pink shrimp has already begun in the Gulf of St. Lawrence, where considerable beds are known in the Mingan and Esquiman channels in the northern part of the Gulf, areas which seem to be optimal for this species. In the exploratory fishing work done in the Gulf, fishing at depths from 113 to 170 fathoms (205 to 310 metres), shrimp trawls yielded up to $400 \mathrm{lbs}$. (180 kg.) per hour's trawling (Squires 1966). From 52 to 83 shrimps make up one pound $(0.45 \mathrm{~kg}$.). This yield compares favourably with the hourly yields obtained in the West Greenland shrimp fishery.

There are clearly real possibilities for development here. In particular, the next step is to carry out exploratory fishing along the Labrador coast and in Davis Strait.

\section{THE "QUEEN CRAB" (Chionocetes opilio)}

This is one of the spider crab group, which is at present being somewhat tentatively fished in the Gulf of St. Lawrence. It is known in West Greenland, the waters of Newfoundland and southern Labrador as far north as Hamilton Inlet (there is one record from deep water east of Cape Chidley), and the Gulf of St. 


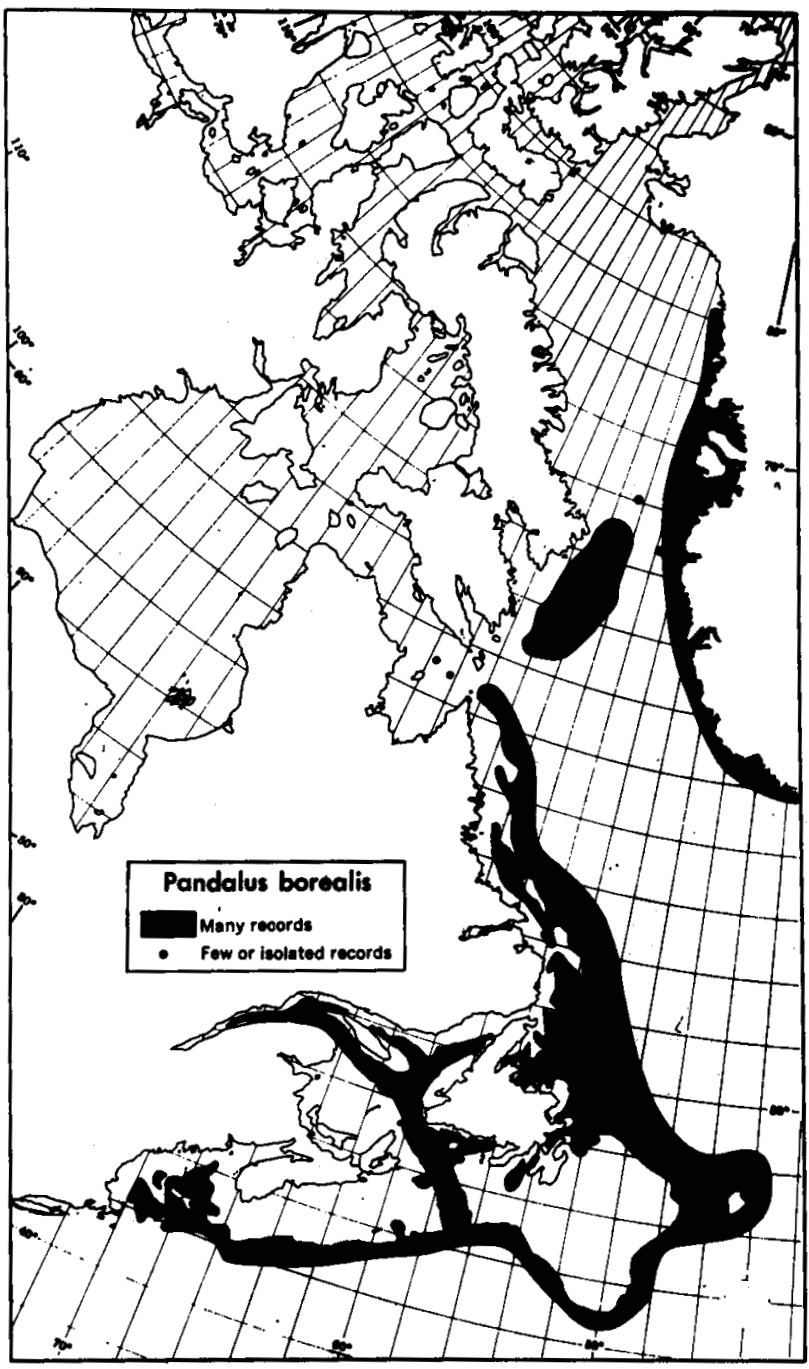

FIG. 5. Western North Atlantic and subarctic distribution of Pandalus borealis, the pink shrimp. From Squires (1966).

Lawrence. It is too early yet to give an opinion on its possibilities in our area, but it should be kept in mind. It is a fairly large crab, a cousin of the Alaskan "King Crab".

\section{THE BLUE MUSSEL (Mytilus edulis)}

The blue mussel is subarctic and boreal in distribution, known in our area from Thule in northwest Greenland (in very small numbers), and from southeast Baffin Island, again only in small numbers. It is reasonably common on the Labrador coast, and extends south to North Carolina. It is eaten by the Eskimos wherever they find it, for it makes a welcome change in diet. As an object for commercial fishery in the north, however, it is a very doubtful prospect. 


\section{THE "PINK NECK" CLAM (Spisula polynyma; syn. Mactra ovalis)}

This is a North American species found on both coasts, mentioned here as an interesting possibility in the Gulf of St. Lawrence. It is fairly large, up to 4 inches $(10 \mathrm{~cm}$.) in breadth, and is reported to be good to eat, but it is not developed commercially anywhere. It is known from the north shore of the Gulf south to Cape Cod, and seven years ago it was the object of an intensive biogeographical study by Chamberlin and Stearns (1963), who have estimated the probability of its successful survival and reproduction on the basis of temperature, depth and bottom sediment type. The shallow water along the north shore of the Gulf of St. Lawrence is classified by these authors as being "partially suitable for both survival and reproduction". The practical possibilities of exploitation, however, have still to be explored. The likelihood of successful exploitation is probably low, but it is worth looking into.

\section{THE SHORT-FINNED SQUID (Illex illecebrosus)}

In his "Marine Resources of Newfoundland", Templeman (1966) writes: "The commercial squid of the Newfoundland area, our greatest molluscan resource, is the short-finned squid. Though large quantities of dried squid were once exported to China for human food, in recent years it has been used almost entirely as bait. Besides being used in the local line fishery for cod, it has been exported as bait, especially for the Portuguese line fishery and the Norwegian and Faroese Longline fishery in the Northwest Atlantic.

"The entire Newfoundland catch is taken close to the shore. On the Newfoundland banks this squid is mainly pelagic and is not readily available in quantity to the otter trawl. In the inshore area, squid usually occupy the shallower water after it has become too warm for large cod and very often after the cod have become bottom feeders in August. Hence, cod and squid do not often come in contact and, though squid is an excellent bait for cod, it is rarely found (other than as bait) in cod stomachs.

"In summer the short-finned squid may be found northward at least to Hamilton Inlet Bank (southern Labrador), westward to the western shore of the Gulf of St. Lawrence, and eastward at least to Flemish Cap. It occurs southward to the Gulf of Mexico and the Caribbean Sea." (Templeman 1966). This squid spawns probably in deep water, and all the individuals that come into the shore are small and immature, but quite large enough to be taken commercially, and they are usually in enormous numbers.

In Newfoundland, the squid fishery varies greatly, from one million to about 23 million pounds (10.4 million $\mathrm{kg}$.) in recent years (1953 to 1964). They are not taken commercially at present in southern Labrador, or in the Gulf of St. Lawrence; probably not a species of great potential in the area considered in this paper.

\section{OTHER INVERTEBRATES}

I have been asked several times why it is not possible to harvest the invertebrates, notably molluscs, which are eaten by walrus. If we estimate the population of Atlantic walrus as 25,000 animals (Mansfield, personal communication), which may be quite reasonable, and the average weight of them to be $2,000 \mathrm{lbs}$. 
( $906 \mathrm{~kg}$.) which may be too high an average, and if we take the figure of 5 per cent of body weight per day as the food requirement, which may also be a little high, then the total live weight of food eaten by the Atlantic walrus population per year comes out at $912,500,000 \mathrm{lbs}$. $(373,000,000 \mathrm{~kg}$.) per year. The Pacific walrus is at least twice as numerous as the Atlantic species, so that this figure must be multiplied by at least a factor of 3 to give the total food requirement, which will be made up very largely of molluscs, almost three billion pounds ( 1.36 billion $\mathrm{kg}$.) of them a year. If, again, we apply the usual 10 percent efficiency figure to this, that is to say, if we assume that the walrus eats only 10 percent of the food available over its feeding range, the total figure has to be multiplied by 10 to give us an estimate of the weight of the total invertebrate standing crop represented. These figures are only for playing with, but at least they show the order of numbers involved.

There is little doubt that dragging for clams in walrus feeding areas would produce large hauls, if they were continued long enough; I do not think the experiment has ever been tried. But it is probable that two important factors would work strongly against the commercial possibilities of using this resource: (1) The clams are probably thinly dispersed, and (2) they are small individually. This means that much energy would have to be expended in their collection, and in their processing. On the whole, I think it is a bad bet. Also, the areas concerned are arctic rather than subarctic, and the growth rate, and hence the rate of regeneration of the resource, would be low.

There is another possible invertebrate resource, namely the zooplankton. The possibility of using the marine plankton as such, directly, as human food, was first seriously proposed in the 1930's, when the threat of war raised food resources to first priority for the prospective belligerents. The United Kingdom and Germany both began practical experiments in the art of plankton fishing, both with rather disappointing results, the Germans at Kiel, the British in Scottish sea-lochs. After the war, the Japanese and the Americans joined the play, the latter with negative conclusions, the former with definitely positive opinions of the feasibility of using plankton as human food. Need, the "black sauce of hunger", obviously played its part in the decisions. The feasibility depends on the type of economy involved and on standards of living. The wartime urgency was not enough to balance the costs involved; but in a peacetime economy based on low labour costs and the Japanese genius for technological inventiveness, it appears to work. At all events, it is reported on reliable authority that phytoplankton (plant plankton) meal is now available in Japan to mix with flour and thus add to the protein value of bread and other baked goods, and that various forms of zooplankton products are available for use in soups, stews, for the enrichment of other dishes, and for sandwich spreads.

This prospect is relevant to northern Canadian waters and human conditions. In the Antarctic, where the whale populations have been drastically reduced by man's economic activities, it is estimated that the amount of zooplankton formerly taken by whales (whales which are now not there) is somewhere between 50 and 100 million tons per year; the evidence for any upswing in other zooplankton eaters (seals, sea birds, fish) is meagre, so that it may be assumed that at least this 
amount of zooplankton is produced in surplus. "At least", because it may also be assumed that even if the whales had not been reduced, enormous quantities of zooplankton could be harvested without disturbing the system. Most of this surplus zooplankton is composed of one dominant species, the euphausid shrimp Euphausia superba, which is a larger species than any euphausid or other zooplankter found in the north; and practical seagoing work is now being done by the Russians to find out the best means of harvesting and processing this species for human consumption.

The difficulties are considerable but at the technological level only; this means that they are soluble. Indeed the problems of harvesting and processing other planktonic populations appear already to have been solved to the satisfaction of the Japanese. One major problem is how to get rid of the exoskeletons, composed of chitin and with sharp points. This material is definitely not healthy; if whole crustacean plankton is fed to rats, they soon die due to the erosion of the mucosa of the intestinal tract by this hard skeletal covering. The obvious way is to put the plankton into large presses and press out the flesh and oil.

Analysis of northern crustacean plankton for food value shows nutritive values just as high as elsewhere in the seas of the world, in terms of protein, fats and vitamins. All that remains to do is to decide on the best places to harvest this product, the best ways to do it, and the best methods of processing and marketing to suit local conditions and tastes. The tastes, of course, have in large part to be cultivated; in other words there are human and social difficulties to overcome as well as technological and biological problems.

We have to go back to the beginning of this paper, in which the basic principles of marine productivity were briefly reviewed. For the plankton as for the fish, the same rules apply, obviously, so that we can at once rule out the Arctic Ocean as such, because of its being basically unproductive. Neither have the waters between the Arctic Islands nor those of Foxe Basin much to offer; and the central Arctic regions (Coronation Gulf and allied regions) can probably also be safely eliminated. The productive capacity of the southern Beaufort Sea area is still not properly explored, so that our attention can be focused on the eastern subarctic region and on Hudson Bay.

Hudson Bay, Ungava Bay, Baffin Bay and the Labrador waters produce zooplankton in abundant quantities, and so does the Gulf of St. Lawrence. Precise quantitative measurements of the production have not yet been made, even in the Gulf (it is being done now, by McGill University), but experience and general rough estimates offer enough evidence to show that the standing crops, in summer at least, are high. Even so, no practical exploitation can proceed without experimental fishing to develop the most effective gear and to choose the most profitable regions and working depths. A pilot expedition is necessary, and so are pilot plants for processing and market investigation and preparation.

It is not possible to go further on this subject at this stage. I have often thought that MacLellan Strait, between Killinek Island (upon which Burwell is situated) and the northern tip of mainland Labrador, offers especially good opportunity for the harvesting of plankton. It is very narrow, deep enough for small ships, and the tidal currents through it are very fast. By mounting large nets across it, es- 
pecially at night, very large catches should be obtained.

As to the species involved, they belong to the euphausid genera Thysanoessa and Meganyctiphanes, the pelagic amphipod genus Parathemisto, and the copepod genera Calanus and Metridia. These are the dominant forms; the first three genera, which are the largest in individual size, figure very largely in the food of seals, fish, and whales.

\section{SEA FARMING}

Commercial fishing has been carried on for centuries, but we are still hunting the fish, in principle as our stone-age ancestors did. We have only just begun to "herd" aquatic animals, particularly marine animals; the cultivation of shrimp and of certain marine fishes by the Japanese is an example, almost the only example. There is no doubt that these techniques will spread, and that the number of species involved will be greatly enlarged. Our immediate concern is whether there will be opportunities for this in our northern sea waters.

The highly indented fiord coastlines of the Labrador and of Baffin Island favour such development; the impounding of fish is made easier and cheaper by such natural coastal formation. The water in many of the fiords is very deep, and the nutrient content of these deep waters is high, so that the necessary conditions for the setting up of artificial upwelling exist. Finally, many of the species described above, all of them common in various northern regions, appear to be likely to lend themselves fairly well to these farming techniques: arctic char, redfish, eel, lumpfish, perhaps Greenland halibut, possibly wolffish and squid. We are, however, some distance from the realization of these ideas, and in any event the subject is so large and specialized as to require special study and special treatment, beyond the limits of this paper.

\section{CLIMATIC CHANGE AND CLIMATIC MANIPULATION}

No report on the subject of future possibilities in northern fisheries would be complete without some discussion of the longer term effects and potentialities. The best place to start is West Greenland, where the climatic warming that has occurred since 1915 has had dramatic and economically decisive effects. There were no Atlantic cod on the West Greenland coast in 1910; today the cod is the mainstay of the economy. Other fishes and other marine resources show the same pattern of change. The reason has been a change in atmospheric and marine climate, involving a rise in the temperature of the core of the West Greenland Current of $2^{\circ} \mathrm{C}$., which represents a great deal of heat. The upswing reached its apparent maximum between 1935 and 1945, and since then there have been alarming cold spells which have had serious effects on the fishery. In the winters of 1948 and 1949, for instance, a return to colder conditions killed vast numbers of cod and shrimp, and caused great anxiety among the Danish administrators of Greenland. The probability at present is that the temporary climatic maximum has been passed and that we may look forward to cooling from now on.

On our side of the Labrador Sea, the effects of this climatic change have been 
less marked, for good oceanographic reasons which need not be spelled out here. The point of bringing this up is that marine climate, by which is meant the prevailing hydrographic conditions in the sea, has a decisive effect on the local marine resources in any region, and in fact upon the total productivity of any given marine area, as has been described in an earlier section. And this means that if man is able, or becomes able, to change the marine climate, he will be in a position to determine which regions of the sea become more or less productive.

For decades, in fact since the 1880 's, Russian engineers, who must have some special itch in this direction, have been proposing to put a dam across Bering Strait, between Siberia and Alaska, in order to change and control the climate of the northern hemisphere. The intent has generally been to reverse the flow through Bering Strait and to pump off the cold arctic water layer from the Arctic Ocean. Backed by some rather primitive and approximate arithmetic, I have gone into print (Dunbar 1960) to push the view that this project is not only impossible, but that it would not achieve the objectives set out for it. This point, however, is not the issue I wish to press here; the important thing is that by operations of analagous nature but less enormous ambition it might be possible to change the hydrographic conditions in certain northern regions to the extent of effecting quite important changes in the biological productivity, and that this is worth thinking about.

A good example is Fury and Hecla Strait, between the mainland of Canada and the northwestern part, or western part, of Baffin Island. This Strait, celebrated in the history of Polar exploration, is narrow and shallow, but a surprising transport of water flows through it to the eastward, perhaps as much as 0.5 Sverdrups, or half a million cubic metres per second, and all this water is arctic, from the upper water of the Arctic Ocean. This is the main source of arctic water that flows (through Foxe Basin) into Hudson Bay, and if that supply were cut off, one would expect Hudson Bay to become warmer throughout and to become less stable, in the vertical column, probably both in summer and in winter. I offer this only as an example for the moment, because it has not been worked out in detail. Another example is the Strait of Belle Isle, the damming of which might keep just enough heat in the Gulf of St. Lawrence to make ice conditions in winter somewhat lighter. This sort of problem must be taken seriously in considering long-term development of northern fisheries.

\section{SUMMARY}

Setting aside the last matter, that of the manipulation of the environment, as a decidedly long-term project, the main points in this review may be summed up as follows:

1. The arctic marine region is not productive, for hydrographic reasons of vertical stability.

2. The Subarctic mixed water region, which is much larger in extent in the Atlantic sector than in the Pacific, is very productive, and much of the important present commercial fishing activity takes place in it. 
3. The Labrador coast and the north shore of the Gulf of St. Lawrence are the most promising regions for fishery development. Both need modern methods designed to meet modern market demands.

4. Within the Arctic zone itself, the only fish that offer possibilities are the Arctic Char and the Greenland Shark, and both are also present in the Subarctic zone.

5. On the Labrador coast, we should focus our attention on the Atlantic Cod, Greenland Halibut, Atlantic Halibut, Capelin, Redfish, Greenland Shark and Pink Shrimp.

6. Secondary possibilities exist in the short-finned squid, the lumpfish, the wolffish, and species that can be used for fishmeal.

7. The north shore of the Gulf of St. Lawrence is at present already supporting certain fisheries, but could be considerably developed.

8. Special attention must be given to the methods of processing, to make the product competitive; especially to freezing and smoking.

\section{REFERENCES}

BIGELOW, H. B. and W. W. WELSH. 1925. Fishes of the Gulf of Maine. U.S. Bureau of Fisheries, Bulletin 40 (1): 1-567.

CHAMberlin, J. L. and F. STEARNS. 1963. A geographic study of the clam, Spisula polynyma (Stimpson). Serial Atlas of the Marine Environment, Folio 3, 12 pp., 6 plates.

DUNBAR, M. J. 1958. Physical oceanographic results of the "Calanus" expeditions in Ungava Bay, Frobisher Bay, Cumberland Sound, Hudson Strait and Northern Hudson Bay, 1949-55. Journal of the Fisheries Research Board of Canada, 15 (2): 155-201.

1960. On the Bering Strait scheme. Polar Notes, II: 1-18.

$119 \mathrm{pp}$.

DUNBar, M. J. and H. H. HILDEBRand. 1952. Contribution to the study of the fishes of Ungava Bay. Journal of the Fisheries Research Board of Canada, 9 (2): 83-128.

GRAINGER, E. H. 1953. On the age, growth, migration, reproductive potential and feeding habits of the arctic char (Salvelinus alpinus) of Frobisher Bay, Baffin Island. Journal of the Fisheries Research Board of Canada, 10 (6): 326-70.

HANSEN, P. M. 1949. Fiskeriundersøgelserne ved Grønland. Grønlandsposten, 8 (8): 98-102.

HANSEN, P. M. and F. HERMANN. 1953. Fisken og Havet ved Grønland. Skrifter fra Danmarks Fiskeri-og Havunders., Nr. 15, 128 pp.

HUNTER, J. G. 1965. Arctic char fishery of the Labrador Coast. Journal of the Fisheries Research Board of Canada, Arctic Biological Station, Annual Report, 1964-65 (Mimeographed). pp. 1-9.

1968. Fish and fisheries. In: C. S. Beals, Editor. Science, History and Hudson Bay. Ottawa: Queen's Printer, vol. 1, pp. 360-78.

JENSEN, A. s. 1925 . On the fishery of the Greenlanders. Medd. Komm. Havunders., Serie Fiskeri, 7 (7): $39 \mathrm{pp}$.

JoRdan, D. S. and B. W. EVERmann. 1896. The Fishes of North and Middle America. Washington: Smithsonian Institution, Vol. 1, $1240 \mathrm{pp}$. 
LEIM, A. H. and W. B. ScotT. 1966. Fishes of the Atlantic Coast of Canada. Journal of the Fisheries Research Board of Canada, Bulletin No. 155, 459 pp.

LE JEUNe, R. 1959. Rapport sur la pêcherie d'ombles chevaliers (Salvelinus alpinus) de Kagnerloualoudjouark (rivière Georges) pour 1959. Québec: Département des Pêcheries, (MS), 67-100.

PADDON, W. A. and D. ANDREWS. 1950. Fisheries of Labrador. Encyclopedia Arctica, Vol. 111, Zoology, Pt. 11, No. 14: 16 pp. (MS).

SCORESBY, W., JR. 1820. An account of the Arctic regions with a history and description of the northern whale-fishery. Edinburgh: Constable, 2 vols.

SQUIRES, H. J. 1966. Distribution of Decapod crustacea in the Northwest Atlantic. Serial Atlas of the Marine Environment, Folio 12, 4 pp. 4 plates.

TEMPLEMAN, w. 1966. Marine resources of Newfoundland. Journal of the Fisheries Research Board of Canada, Bulletin No. 154, $170 \mathrm{pp}$.

TURNER, I. M. 1885. Fishes. Manuscript report, deposited with the Smithsonian Institution, Washington, D.C., and copy at McGill University, Redpath Library. 